\title{
Henry Brougham Guppy, F.R.S.
}

IN Surgeon Henry Brougham Guppy we have another brilliant example of the brotherhood of Medicine and Natural History, which from the days of Aristotle has been so conspicuous in the annals of science. He was the twin son of Dr T. S. Guppy, a well-known and able physician of Falmouth, and from early days was thus guided and encouraged in the career he subsequently followed. After receiving education at King's School, Sherborne, he entered the Medical School of St Bartholomew's Hospital, then studied in Edinburgh University, and graduated as M.B. and C.M. Joining the Navy he served as Surgeon on board H.M.S. Hornet, seeing much that was interesting in the seas of China and Japan; indeed, throughout the active period of his life he had extensive experiences of foreign lands and seas which led to many important researches in so gifted an observer of Nature. Thus in H.M.S. Lark, a surveying schooner, he had many opportunities in the W. Pacific of studying volcanoes, the formation of coral reefs, and the dispersal of plants in the Keeling and other islands. As much a geologist as a zoologist and botanist he brought all three to bear in his extended observations. Encouraged by Dr Gunther of the British Museum, who was interested in the young surgeon-naturalist, he set out in the beginning of 1881 in H.M.S. Lark. During this expedition he made large collections illustrating the Geology and the Life of the Natives of the Solomon Islands, publishing in 1887 a work in two volumes on the Natives and Geology and Zoology, illustrated by plates and maps. In his various excursions in regions perhaps seldom or never visited by a European he ran considerable risk, but throughout his whole career he was noted for his fearless search for information. A traveller who could climb all the chief mountains in Hawai and Fiji, and spend twenty-three days alone on the summit of Manua Loa volcano, 13,670 ft. high, was not a man to trouble himself about tropical rain-torrents, or be diverted from his observations by dense forests, where tracks were few, or by swollen rivers, or by the absence of all paths except the torrent's bed. His bearing and tact with the natives (to whom the two volumes are dedicated) were also important elements in his success. These two volumes alone wonld have entitled him to distinction. But his busy life in the Pacific resulted in further contributions to the Natural History of these regions, viz. in other two volumes of Observations published in 1903 and 
1906. The geological and general features-especially of Vanua Levu, one of the Fiji group-were carefully described, his conclusion being that the islands were always isolated and not parts of a continent. Moreover, his botanical studies enabled him to contribute important observations on plant-dispersal, a field in which his extensive travels on sea and land enabled him to utilize with great success. His acute powers of observations in regard to the oceanic currents as well as those of fresh water, in relation to the buoyant or heavy seeds or seed-capsules, resulted in the extension of our knowledge on this subject, just as his observations on the inland extension of beach-plants, their mode of dispersal and the plants of the Pacific Islands in general, as well as insular floras and those of the west coast of South America, largely added to our information. These important volumes still further increased his reputation as an earnest and original worker, and led to his election to the Royal Society (1918). His discovery of many hot springs in Vanua Levu, his botanical report on the Challenger Expedition, his studies on the formation of coral reefs and their fauna and flora all show the lifelong and unwearied search for truth, and his inherent love of Nature. In connection with the formation of coral reefs he had many communications with Sir John Murray, whose theory on the subject coincided with his own, while he criticised Darwin's theory of subsidence. Most zoologists were interested in Dr Guppy's observations on coral reefs, and indeed it was these which drew their attention towards him, yet. on the botanical and geological sides he had accumulated a great store of information after many adventures in his Rob Roy canoe. He lost no opportunity, however, of adding to zoological knowledge, as indicated by his notes on the pearls of Tridnaca, the pearly or luminous organs of Scopelus, and the structure of the gizzard of oceanic birds. The labour he took in satisfying himself as to the accuracy of statements in zoological literature was well shown in his study of the food of the holothurians on coral reefs. He found that those examined fed on dead coral or coral detritus, and that each excreted $\frac{2}{5}$ of a pound daily, so that he thought the combined action of fishes, echinoderms, annelids, and other forms would prevent certain coral reefs from rising above the surface.

Besides the regions mentioned, Dr Guppy was familiar with the Pacific side of South America from the Strait of Magellan to Panama, with Teneriffe, the Azores, and the West Indies. He also was the author of a work Homes of Family Names.

Taken all in all, H. B. Guppy stands prominently out as a scientific naval surgeon-a class so well exemplified in T. H. Huxley, Dr Moss, and others-just as W. H. Flower was a fine type of the military surgeon. 
The fortitude and determination which, with a suavity that rendered every native his friend, carried him through many difficult and often dangerous inland journeys, his vigour in scaling mountains and braving exposure to climatic vicissitudes, awaken admiration, no less than his scientific labours in anthropology, geology, and botany. His genius as a naturalist enabled him to surmount all obstacles of position and occupation, and to leave a worthy record behind him.

Retiring from the Navy, he devoted himself entirely to scientific research. Starting in January of this year (1926) for Tahiti to continue his observations, he suffered from bronchitis there, and returning home he died suddenly from heart failure at Fort de France, Martinique, at the age of 71, on 23rd April.

He was elected a Fellow of this Society in 1888, and contributed to its publications.

W. C. M. 